\title{
The Effectiveness of One Roof School Program in Magelang Indonesia
}

\author{
Wiwik Wijayanti \\ Educational Management \\ Universitas Negeri Yogyakarta \\ wiwik_wijayanti@uny.ac.id
}

\begin{abstract}
The objective of this study was to find out the effectiveness of the management process of One Roof elementary - junior high school in Magelang district, Central Java including educators and officers, infrastructure, curriculum, school organization/ institution, and students. The method of data collection was done by open- and closed- questionnaire, and then the data were analyzed by quantitative approach particularly by using quantitative-descriptive type. The findings showed that as follows: 1) the educators and officers were categorized as quite effective, 2) the curriculum was in the effective category, 3) the organization/institution was categorized as effective, 4) the infrastructure belonged to the category of quite effective, and 5) the students were in the category of quite effective.
\end{abstract}

Keywords-One Roof School, Rural education

\section{INTRODUCTION}

Basic education is common education which held for six to nine years. Basic education (basic foundation) is held in order to prepare student to be a citizen which is faith full, able to conduct citizen's responsibilities, and has basic skill to be applied in work in a society [1]. And almost every first-grader rises to that next step of his life as a "Tabula Rasa", since the pre-school education, which he has just received, is mostly focused on primary socialization of him as a person, and not on obtaining the skills and abilities required for further learning [2].

Commonly, the purpose of basic education is to prepare student to be (1) moral people; (2) a citizen which is able to conduct their responsibilities; and (3) adult people which can get a job by giving student common basic skill for all jobs in a society [1].

The main purpose of basic education is to help student in developing themselves to become a human which has high intelligence, good mentality, autonomous, love to work for charity, and is ready to face changes [3]

One way that can be done in remote, dispersed, and isolated place is by bringing the Junior High School to location where children who have not get education concentrate [4]. This can be done by developing Combined Basic Education in existed Elementary School or what we call
One Roof Elementary School - Junior High School. The development of this Combined Basic Education joins combines the location of Junior High School and the location of Elementary School by taking advantage of various resources and facilities from the existed Elementary School [5] [6].

The success of school is micro measure which is based on purpose and target of education in school which match the purpose of national education and how far this purpose can be achieved in certain period appropriate with the period of education in school. Therefore, a school is said to be effective when there is solid relation between what has been formulated and what has been achieved. Meanwhile, school is said to be ineffective when the relation is low [7].

The implementation of One Roof Elementary School Junior High School which has been started since 2006 needs evaluation. This evaluation is intended to measure whether the implementation has fulfilled the standard or is far from expectation. This research is aimed to know the effectiveness of the implementation of One Roof Elementary School Junior High School in Magelang regency.

\section{RESEARCH METHOD}

This research uses quantitative approach. The subject of this research is One Roof Elementary School - Junior High School in Magelang regency. The object of this research is the effectiveness of the process of the implementation of One Roof Elementary School - Junior High School which covers human resource, facilities, curriculum, organization/institutional, and student. Data collecting uses questionnaire which is given to headmaster and teachers in One Roof Elementary School - Junior High School. The analysis of collected data is conducted by comparing achievement aspect with given standard and categorizing [8]. The categorization of the effectiveness here considers the effectiveness of process only, therefore what we measure is not the effectiveness of the output. The categorization of the effectiveness of the process is formulated by considering the condition of amount, quality, and utilization. If the condition 
of amount, quality, and utilization have been fulfilled, it can be said to be effective.

\section{RESULTS AND DISCUSSION}

\section{A. Teacher and Staff Aspect}

According to research result, the most common problem concerning human resource is on the rule which makes teacher to work 24 hours a week with cluster system. Another common problems are geographical location of school which is far from home, performance which is admitted to be not maximal, the ability of teacher in using visual aid and learning source, and complaint concerning the status of human resources who have been Government Civil Servant [9]. It seems that the problem concerning the status of human resources who have been Government Civil Servant is related to recruitment system which is still complained. The problem concerning the number of human resource becomes respondents' attention too. Meanwhile, prosperity problem is on the last rank.

From the aspect of the number of teacher, respondents answered that the number is sufficient. However, other respondents said that most human resources are not Government Civil Servant. In addition, there are still teachers who teach double subjects due to the lack of teacher of this subject.

\section{B. Facilities Aspect}

The most mentioned obstacle in facilities aspect is the nonexistent of library and Science/Language laboratory. Another obstacles is the non-existent of classroom, praying room, computer, and sport field. The interesting thing is that respondents think that things that support learning process directly are not mentioned. These things are projector, sports utility, visual aid, table and chair for student, and learning book. In other words, it can be said that the existence of tools that support teaching-learning process directly is sufficient.

Based on the elaboration above, it can be concluded that considered from sufficiency and completeness, facility is not completely sufficient. Even the existed facilities have not been utilized as they should have been so that facilities aspect can be said to be effective enough.

\section{Curriculum Aspect}

Morgan (2004) said that in the development of capacity there must be the internal process of growth and development and result-oriented efforts. United Nation Development Program (UNDP) recommended that the groups of the development of capacity must be able to guide their members to implement the essential functions, to solve problems, and to decide and to achieve goals. In addition, the groups of the development of capacity must be able to make their members understood and be able to fulfill the need of their selfdevelopment continuously.

Based on the elaboration above, it can be known that the curriculum implemented in those schools are based on national curriculum. Moreover, teachers implement the curriculum by making syllabi and Teaching Plan. It is also found that teachers have already tried to develop their skill/competency by joining Conference of Subject Teacher or by asking/discussing with senior teacher. However, it is still need to push them to optimize the Conference of Subject Teacher itself. In conducting teaching duty, teachers use Teaching Plan as guide and the principal supervises them directly or indirectly. The aspect of curriculum can be said to be effective enough.

\section{Organizational/ Institutional Aspect}

The existence of One-Roof School in Magelang Regency is very supported by surrounding society, considering historically the existence of One-Roof School is the part of the need of society in remote area [10]. Based on research data, it is revealed that commonly society's support towards school is good enough. There is only a few respondents who stated that society's support is insufficient. On the contrary, most respondents said that there is society's involvement in OneRoof School. In other words, society contributes not only on financing but also on another aspect like contribution in the form of force, time, and ideas in school duty programs [11].

Based on the elaboration above, it can be said that school makes effort to make betterment and improvement through strategic plan to achieve vision and mission. Society's support is high. This support is in the form of participation of sending their children to attend school, ideas contribution, and support of school duty programs. In the aspect of institutional, the researcher categorized its process as effective.

\section{E. Student Aspect}

Extracurricular activity which is often mentioned to be existed in Boy/Girl Scout. The obstacle of the implementation of extracurricular activity which is often mentioned comes from the lack of teacher who teaches extracurricular activity. The lack of tools and facility is also said to be the obstacle. Based on previous research result concerning One-Roof School, it is said that student input has no great academic skill.

Based on the elaboration above, it can be concluded that teachers have made effort to give motivation to students through various ways. Guidance program which is given to students has not been able to fulfill students' need due to the lack of human resource and tools. The aspect of student can be said to be effective enough.

\section{CONCLUSION}

Based on research result, we can conclude that:Teacher and staff aspect is categorized as effective. It can be seen from the number of teacher which is sufficient although it is not spread evenly in all subjects. Talking about quality, there are teachers in those six schools who do not teach based on their skill field. In conducting duty, teachers are not maximal since school is far from their homes. Their performance is also low. However, talking about employment status, all teachers have already had employment status like Government Civil Servant, PTT, and GTT.

Facilities aspect is categorized as effective enough. Based on completeness and sufficiency, facilities aspect is still far 
from the standard. Even the existed facilities have not been utilized optimally.

Curriculum aspect can be categorized as effective. This is based on curriculum implemented in those schools is based on national curriculum. Furthermore, teachers implement this curriculum by making syllabi and RPP. In conducting teaching duty, teachers use RPP as a guide and the principal supervises the teachers

Organization/institutional aspect is categorized as effective. Society's support is in the form of participation of sending their children to attend school, ideas contribution, and support of school duty programs.

Student aspect is categorized effective enough. Teachers have made effort to motivate students. Guidance program which is given to students has not been able to fulfill students' need due to the lack of human resource and tools.

\section{ACKNOWLEDGMENT}

Thanks to Universitas Negeri Yogyakarta in that has funded this research. This article is of a study with the title of The Effectiveness Of The Implementation Of One Roof Elementary - Junior High School In Magelang District, for that we say thank you to Rahmania Utari who have collaborated in this study.

\section{REFERENCES}

[1] Adler, M.J, The Paideia Proposal: An Educational Manifesto. New York: Macmillan Publishing Co, 1982.

[2] Gusarova A, Performance" and "morality" as main goals of elementary schools in Japan. Procedia - Social and Behavioral Sciences 182, 2015 $692-694$.

[3] Collier, C.C., Houston, W.R., Schmatz, R.R.,\& Walsh, W.J, Teaching in The Modern Elementary School. New York: The Macmillan Company, 1971.

[4] Elsbree, W.S., McNally, H.J.,\& Wynn, R, Elementary School Administration and Supervision ( $3^{\text {rd }}$ edition). New York: American Book Company, 1967.

[5] Beeby, C.E, Assesment of Indonesian Education. A Guide in Planning. Wellington: Oxford University, 1979.

[6] Davis, G. A., \& Thomas. M. A, Effective Schools and Effective Teachers. Boston: Allyn \& Bacon, 1989.

[7] Scheerens, J., Vermeulen, C.J.A.J. and Pelgrum, W. J, Generalizibility of Instructional and School Effectiveness Indicator Across Nations. International Journal of Educational Research, 13 (7), 1989,789-799.

[8] Guba, E. G., \& Lincoln, Y.S, Effective Evaluation: Improving the Usefulness of Evaluation Result Trough Responsive and Naturalistic Approaches. San Francisco, California: Jossey-Bass Inc. Publisher, 1981.

[9] Heck, S.T., William, C.R, The Complex Roles of The Teacher: an Ecological Persective. New York: Teachers College Press, 1984.

[10] Scheerens, J. \& Bosker, The Foundation Of Educational Effectiveness. New York: Pergarmon, 1997.

[11] Levine, D. V., \& Lezotte, L. W. (1990). Unusually effective schools: A review and analysis of research and practice. Madison, WI: The National Center for Effective Schools Research and Development. 